\title{
Potential Causes Of Poverty In The City Of Probolinggo
}

Tatik Amani, Yekti Rahajeng, Hermanto

Panca Marga University

Email: tatikamani@upm.ac.id

\section{A R T I C LE IN F O}

Date of entry:

O8 July 2020

Revision Date:

22 August 2020

Date Received:

13 September 2020

\begin{abstract}
A B S T R A C T
Poverty is a situation where humans cannot achieve their basic requirements. This has become a standard problem experienced by every country. The research object aims to find the potential causes of poverty in the Probolinggo by examining the effect of the potential for education, unemployment, and inflation simultaneously, partially and dominantly, on poverty. The study used a quantitative method of causal relationships, 391 RTM respondents with cluster sampling technique sampling. The data analysis method used a validity test, reliability test, classical assumption test, multiple linear regression analysis, and determination coefficient analysis. The conclusion from the hypothesis testing in this research is the variables of education, unemployment, and inflation have a significant and partial effect on poverty in Probolinggo City, while the most dominant potential effect on poverty is education. The result of the determination coefficient analysis is $71.9 \%$. The causes of poverty in the city of Probolinggo are education, unemployment, and inflation. From the research results, the local government should continue to motivate and make people aware of the importance of education, improve skills as a means of overcoming unemployment, increase economic growth so the inflation can be suppressed, and the problem of poverty is resolved.
\end{abstract}

Keywords: Education, Unemployment, Inflation, Poverty

Cite this as: Amani, T., Rahajeng, Y., Hermanto, H. (2020). Potential Causes Of Poverty In The City Of Probolinggo. Wiga : Jurnal Penelitian Ilmu Ekonomi, 1O(2), 157-162. https://doi.org/10.30741/wiga.v10i2.598

\section{INTRODUCTION}

Poverty is a situation where humans cannot achieve their basic requirements. This problem could be seen in various aspects because poverty is a multidimensional problem not only related to economic conditions but also social and cultural conditions. Basically, poverty is connected to a person's lack of access to education, health, and infrastructure facilities. Poverty has become a classic problem experienced by every country, including in Indonesia, including in the City of Probolinggo. The efforts to deal with poverty by the Mayor of Probolinggo are very serious, even becoming one of the priority programs. It is proven by the percentage of poverty reduction that continues year by year. It can be seen in the following table: 
Table 1. Poverty Level Data for the City of Probolinggo 2015-2019

\begin{tabular}{|c|c|c|c|c|c|c|}
\hline Description & Unit & 2015 & 2016 & 2017 & 2018 & 2019 \\
\hline $\begin{array}{l}\text { Number of Poor } \\
\text { People }\end{array}$ & $\begin{array}{l}\text { thousand } \\
\text { inhabitants }\end{array}$ & 18,66 & 18,37 & 18,23 & 16,9 & 16,37 \\
\hline $\begin{array}{l}\text { Percentage of } \\
\text { Poor Population }\end{array}$ & $\%$ & 8,17 & 7,97 & 7,84 & 7,20 & 6,91 \\
\hline $\begin{array}{l}\text { The poverty of } \\
\text { Depth Index (P1) }\end{array}$ & - & 1,36 & 0,98 & 0,92 & 0,89 & 1,04 \\
\hline $\begin{array}{l}\text { The poverty of } \\
\text { Severity Index } \\
\text { (P2) }\end{array}$ & - & 0,37 & 0,20 & 0,18 & 0,17 & 0,26 \\
\hline $\begin{array}{l}\text { Pover Poverty } \\
\text { Line }\end{array}$ & Rp/Capital/Month & 403.037 & 418.480 & 437.392 & 479.267 & 501.505 \\
\hline
\end{tabular}

Source: Central Bureau of Statistics for The City of Probolinggo, 2020.

Knowledge and skills of a person will increase if they have a high level of education, so that will also increase work productivity. The relationship between poverty and education is very important because education is able to provide development through one's knowledge and skills.

Education also puts forward awareness of the importance of position or dignity as a human being, so that education is a potential cause of poverty. Income level is another determining element in the prosperity of a society. Community income can reach the maximum if the level of employment is not unemployed. The reduction in people's income is one of the effects of unemployment. The lower the unemployment rate, the more welfare will increase and reduce poverty or vice versa with unemployment, it will be a potential cause of poverty. Inflation also affects poverty, a condition where prices tend to continually increase in the economy. Inflation is found in almost all countries, including Indonesia. There is a difference in the percentage of inflation in each country at each period. Based on this background, this research aims to achieve to analyze the effect of education, unemployment, and inflation simultaneously, partially, and dominantly on the poverty of the people in the City of Probolinggo.

Education is a learning process that is given to civilized humans in the field of assessing knowledge with teaching methods. There are several levels in taking education according to the level of development of students, which aim to increase morale, reason, and skills as human resources of a country. "Education is social capital for the continuity of Indonesia's future development" Indrajit (2014: 31). Lexically quoted in the Webster dictionary, the word education which in other languages can be interpreted as (a) the action of educating to be educated; (b) development and knowledge of the educational process; or (c) a study of teaching and learning methods in schools (Hasibuan, 2019). Education is the process of humanizing young people (Ramdhan, 2018).

Unemployment is a problem that must be faced by human resources who are trying to get a job but have not yet got it. The jobless situation faced by a group of workers who have tried to find work but did not get it (Nursalam, 2013). Individuals who face this problem are called unemployed. If the unemployed do not have a job at all, this is known as open unemployment. Unemployment is caused by the disproportionate number of the labor force and employment opportunities in a country (Albertus Aditya, 2020).

The definition of inflation is a phenomenon where the price tendency of a country's goods has increased drastically and continuously. In this inflationary trend, this tendency is broad in that the prices of goods have increased drastically in almost a whole manner (Boediono, 2014). 
Poverty is a condition of a person in fulfilling the needs of both clothing, food, and shelter in a family, community, even a country, which results in discomfort in life. Poverty can occur due to several factors that support not only a person's internal but also external. Poverty is an economic disease that affects many countries but does not affect all of them with the same frequency. People who have a small share of national income are usually called poor, while those with a large share are referred to as rich people (Danim, 2013). Poverty is a global social problem. This means that poverty is a problem faced and a concern of many people in this world (Boediono, 2014)

\section{METHOD}

This research uses quantitative methods with causal relationships, namely relationships that have causal properties, meaning that there are variables that influence (independent) and variables that are affected (dependent). This study aims to determine the relationship between education, unemployment, inflation on poverty, and the magnitude of its effects both simultaneously and partially. The research analysis tool used multiple regression analysis, namely the model: $\mathrm{Y}=\mathrm{a}+$ $\mathrm{b} 1 \mathrm{x} 1+\mathrm{b} 2 \mathrm{x} 2+\mathrm{b} 3 \times 3$. Where: $\mathrm{Y}=$ Poverty, $\mathrm{a}=$ Constant, $\mathrm{X} 1=$ Education, $\mathrm{X} 2=$ Unemployment, $\mathrm{X} 3$ = Inflation, $\mathrm{b} 1=$ Education Coefficient, $\mathrm{b} 2=$ Unemployment Coefficient and b3 = Inflation coefficient using SPSS 22 application assistance. In order for regression to conclude valid research results, it begins with testing the legitimacy of the data sample and the reliability that has been determined based on the Slovin formula of a predetermined population of poor people-followed by the classic assumption test, namely the multicollinearity test, autocorrelation test, heteroscedasticity, and normality. Then the next step can be done by testing the hypothesis so that readers can evaluate the suitability of the method, the reliability, and the validity of the results.

\section{RESULTS AND DISCUSSION}

The data analysis test carried out by this research is data quality test, classic assumption test (multicollinearity, autocorrelation, heteroscedasticity, and normality test), multiple linear regression analysis, coefficient of determination $\left(\mathrm{R}^{2}\right)$, and hypothesis testing performed with the help of a computer program IBM SPSS Statistics 22.

The validity test in this study is by comparing a Sig (2-tailed) value of the output (corrected itemtotal correlation) less than 0,05 . Sig (2-tailed) is smaller than 0,05 , so the statement item is said to be valid. But if the opposite is true, the statement item is said to be invalid. Validity test in this Educational research variables X1.1 to X1.9 with a Sig (2-tailed) value of 0,000 are declared valid, Unemployment variables X2.1 to X2.10 with a Sig (2-tailed) value of 0,000 are declared valid, Inflation variables X3.1 to X3.7 with a Sig (2-tailed) value of 0,000 are declared valid, and the Poverty variables Y.1 to Y.10 with a Sig (2-tailed) value of 0,000 are declared valid. So it can be concluded that each variable is declared valid, and all statement items can be used and trusted (Source: Primary data processed).

Reliability testing in this study used Cronbach's Alpha method using the SPSS 22 Application. Educational variables are 0,777, Unemployment variables are 0,720, Inflation variables are 0,699 and Poverty variables are 0,771 . The reliability test results of this study have a Cronbach's Alpha value greater than 0,60, then all variables are declared reliable (Source: Primary data processed). The multicollinearity test is used to determine whether there are similarities between the independent variables in a model. According to Sujarweni, if the resulting VIF is between 1-10, then multicollinearity will not occur. 
Based on the data that has been presented by using alpha or tolerance $10 \%$ or 0,1 then VIF $=1$ from the output, the VIF for education (X1) is 1,273 , VIF for unemployment (X2) is 1,577 , and VIF for inflation (X3) 1,277 is greater than VIF $=1$ and the tolerance variable for Education (X1) is $0,786=78,6 \%$, the Unemployment variable $(\mathrm{X} 2)$ is $0,634=63,4 \%$, and the Inflation variable (X3) is $0,783=78,3 \%$ is above 0,1 or $10 \%$, it can be concluded that there is no multicollinearity between the independent variables.

The autocorrelation test aims to test the correlation between confounding errors in observational data in an observation. Following are the results of the autocorrelation test : From the results above, it is found that the Durbin-Watson test is 1,034 and $-2 \leq \mathrm{DW} \leq+2$. It can be concluded that the above data does not occur autocorrelation. This test is used to test the difference in residual variance from one observation period to another. The results of the heteroscedasticity test are as follows: The analysis of the results of the SPSS scatterplot output above shows that the points are spread and do not converge in one place. So, the conclusion is that the independent variable above does not apply to occur heteroscedasticity.

The normality test aims to determine which confounding or residual variables have a normal distribution in the regression model. The following are the results of the normality test using a histogram graph and a normal probability plot. From the results of the histogram graph, the results of the normal curve line are obtained, which means that the data under study is normally distributed, while the diagonal lines are followed by data that spreads around and in the direction of the diagonal lines, which means that the distribution pattern is normal.

Multiple regression aims to determine whether or not two or more independent variables have a significant influence on the dependent variable. The results of the multiple regression analysis tests can be seen in the following table:

Table 2. Multiple Regression Analysis

\begin{tabular}{llrrrrr}
\hline \multirow{2}{*}{ Model } & \multicolumn{2}{c}{ Unstandardized Coefficients } & $\begin{array}{c}\text { Standardized } \\
\text { Coefficients }\end{array}$ & \multicolumn{1}{c}{ T } & Sig. \\
\cline { 2 - 5 } & B & Std. Error & \multicolumn{1}{c}{ Beta } & & \\
\hline 1 & (Constant) & $-5,694$ & 2,162 & & $-2,634$ & 0,009 \\
& Education & 0,552 & 0,029 & 0,587 & 19,313 & 0,000 \\
& Unemployment & 0,804 & 0,063 & 0,435 & 12,863 & 0,000 \\
& Inflation & 0,272 & 0,072 & $-0,114$ & 3,759 & 0,000 \\
\hline
\end{tabular}

Source : Primary data processed, 2020

So that the multiple linear regression equation is obtained as follows: $\mathrm{Y}=\mathrm{a}+\mathrm{b} 1 \mathrm{X} 1+\mathrm{b} 2 \mathrm{X} 2+$ b3X3, Y $=-5,694+0,552 \mathrm{X} 1+0,804 \mathrm{X} 2+0,272 \mathrm{X} 3$. 1) It is known that a constant value of 5,694 states that if there is no Education variable (X1), the Unemployment variable (X2), and Inflation variable (X3), a value of $-5,694$ will be obtained. 2) Regression coefficient b1 Education $=0,552$ states the coefficient value for variable $\mathrm{X} 1$ is 0,552 and is positive. This indicates that the education variable has a direct relationship with poverty. 3) Regression coefficient b2 Unemployment $=0,804$ states the coefficient value for variable $\mathrm{X} 2$ is 0,804 and is positive. This indicates that the unemployment variable has a direct relationship with poverty. 4) Regression Coefficient b3 inflation $=0,272$ states the coefficient value for variable X3 is 0,272 and is positive. This indicates that the inflation variable has a direct relationship with poverty.

The coefficient of determination (R2) is 0,719 . This means that $71,9 \%$ of the dependent variable Poverty is influenced by the independent variables Education, Unemployment, and Inflation. At the same time, the remaining $28,1 \%$ is influenced by variables other than the variables in the study. 
The test results show that the value of $\mathrm{F}$ count 330,143 is greater than $\mathrm{F}$ table 2,627 with a sig. $\mathrm{F}=$ $0,000<0,05$ means that the independent variables simultaneously (together) have a significant effect on the dependent variable. Based on the results of the F test, it is proven if the first hypothesis can be accepted, namely, "There is a simultaneous influence between Education (X1), Unemployment (X2), and Inflation (X3) on Poverty (Y) in Probolinggo City.

The partial test is a test used to test the ability of the regression coefficient partially, the results of the test partially 1 (t-test). Testing the hypothesis partially are : 1) Variable X1 (Education) obtained $t$ count $(19,313)>t$ table $(1,966)$ with sig. $=0,000$, because the value is sig. $<0,025$, this means that there is a significant influence between education on poverty. 2) The variable X2 (unemployment) obtained the value of $t$ count $(12,863)>t$ table $(1,966)$ and the value of sig. $=0.000$, because of the value of sig. $<0,025$, this means that there is a significant influence between unemployment and poverty. 3) Variable X3 (Inflation) obtained t count $(3,759)>t$ table $(1,966)$ and sig. $=0,000$, because of the sig. $<0,025$, this means that there is a significant influence between inflation and poverty. Thus, it is proven if the second hypothesis can be accepted, namely, "There is a partial influence between Education (X1), Unemployment (X2) and Inflation (X3) on Poverty (Y) in the City of Probolinggo.

The dominant variable has an effect on poverty. This is indicated by the t count of education (X1) $=19,313$ with a sig. $\mathrm{t}=0,000$ is greater than the $\mathrm{t}$ count of unemployment variable $(\mathrm{X} 2)=12,863$ with a sig. $t=0,000$ and the inflation variable $(X 3)=3,759$ with a sig. $t=0,000$. Thus, it is proven if the third hypothesis can be accepted, namely "Education (X1), which dominantly affects the Poverty (Y) of the people in the City of Probolinggo".

\section{CONCLUSION}

The conclusion of the results of hypothesis testing in this study is that the variables of education, unemployment, and inflation have an important and partial effect on poverty in Probolinggo City, while the most dominant potential that affects poverty is education. The coefficient of determination analysis the result showed that $71,9 \%$ of the causes of poverty in the city of Probolinggo were education, unemployment, and inflation. From the research results, the local government should continue to motivate and make people aware of the importance of education, improve skills as a means of overcoming unemployment, increase economic growth so that inflation can be suppressed, and the problem of poverty is resolved.

\section{ACKNOWLEDGEMENT}

This paper and the research behind it would not have been possible without the extraordinary support of all parties. Thankful to LLDIKTI VII for providing research funding. To the City of Probolinggo agencies (Bakesbangpol, BPS, Mayor, Polsek, and All Probolinggo City Districts) who have provided research permits and data. The entire research team, both members and research assistants contributed to completing the research. I am especially grateful also to all respondents of the Probolinggo City community who are willing to take the time to fill out the questionnaire as research data.

\section{REFERENCE}

Aditya, A. (2020). "Pengangguran" https://id.m.wikipwdia.org/wiki/pengangguran, diakses Juli 2020.

Badan Pusat Statistik Kota Probolinggo. (2020). Indikator Kesejahteraan Rakyat Kota Probolinggo 2019/2020. Probolinggo: Badan Pusat Statistik Kota Probolinggo. 
Boediono. (2014). EkonomiMikro. Yogyakarta: BFFE, 2014.

Hasibuan, S. N., Juanda, B., \& Mulatsih, S. (2019). Analisis Sebaran Dan Faktor Penyebab Kemiskinan Di Kabupaten Bandung Barat. Jurnal Agribisnis Indonesia, 7(2), 79-91. https://doi.org/10.29244/jai.2019.7.2.79-91

Wisnu, I. dan Soimin. (2014). Pemberdayaan Masyarakat dan Pembangunan Gagasan Manajemen Pengembangan Masyarakat untuk Memutus Mata Rantai Kemiskinan. Malang: Intrans Publishing.

Nursalam. (2013). Metodologi Penelitian Ilmu Keperawatan-Pendekatan Praktis, 3rd ed. Jakarta: SalembaMedika, 2013.

Ramdhan, D. A., Setyadi, D., \& Wijaya, A. (2018). Faktor-faktor yang mempengaruhi tingkat pengangguran dan kemiskinan di kota samarinda. Inovasi, 13(1), https://doi.org/10.29264/jinv.v13i1.2434

Danim, S. (2013). PengantarPendidikan. Bandung: Alfabeta 